\title{
Development of Academic Speaking Communicative Tasks Model for Students of English Education
}

\author{
A Amrullah* \\ English Department \\ University of Mataram \\ Mataram, Indonesia \\ amrullahmpd@unram.ac.id
}

N Nawawi

English Department

University of Mataram

Mataram, Indonesia

\author{
Lalu Thohir \\ English Department \\ University of Mataram \\ Mataram, Indonesia
}

\author{
S Sahuddin \\ English Department \\ University of Mataram \\ Mataram, Indonesia
}

\author{
H Henny \\ English Department \\ University of Mataram \\ Mataram, Indonesia
}

\begin{abstract}
This study aims to determine the appropriate communicative tasks model to maximize the English students' presentation skills at the English study program, University of Mataram, and to identify the obstacles experienced by lecturers who teach academic speaking subjects in the tasks that have been prepared. This study adopted a development procedure model based on Gall [1] such as a) Obtaining information consisting of identifying problems, choosing problem-solving tools, and theoretical studies. b) Choosing teaching materials that consist of techniques, teaching, and learning processes. c) Summarize the teaching material. d) Present. d) Evaluating. e) Completion which consists of developing the final product for academic speaking teaching materials. The results of the needs assessment discuss the data collected from questionnaires, observations, and documentation. The results showed that the presentation assignment was the most important part of the lecturers' assessment of students in conveying the main ideas of their reading. Meanwhile, the obstacles faced by lecturers with the tasks that have been prepared are grouped into two aspects, namely linguistic and non-linguistic. Linguistic factors include the ability to choose and use the right vocabulary according to pronouncing English words correctly and using tenses according to the context. Meanwhile, the non-linguistic factors analyzed included aspects of self-confidence, anxiety, and mastery of the topic of the assigned material when appearing in front of the class.
\end{abstract}

Keywords-development, communicative tasks, academic speaking

\section{INTRODUCTION}

This research that has been conducted is motivated by the low English-speaking ability of English students' programs when conveying their ideas when learning takes place in the classroom. This situation keeps happening even though they are learning speaking 1 to 3, public speaking, and academic speaking. As a lecturer who teaches public speaking and academic speaking subjects, it is deemed necessary to find alternative solutions to improve the ability of students to speak English. For example, in an academic speaking course, students are expected to be able to present their ideas in a formal, systematic, and comprehensive manner. Even so, the learning expectations have not been maximally achieved because when students present their proposal exams and theses, many of them are not able to verbally communicate their ideas in English. When students present their thesis material, they are seen reading the slides shown or their notes more when it should not have happened. Therefore, one of the urgent efforts to be made in overcoming this is the existence of communicative tasks that must be prepared by lecturers who are teaching academic speaking subjects.

Based on Amrullah's [2] previous experiences and research conducted by the researcher, there are several causes for the students' low English-speaking ability. First, the lecturer has not optimally prepared a set of tasks [individual tasks, pair works, and group works] during the learning process. Second, lecturers do not provide many opportunities for students to speak English, learning takes place in class. Third, there is no strict discipline for students who use English when conveying their ideas in the classroom. Several previous studies related to tasks-based learning have shown relatively similar results, for example, Prabhu [3], Rattanawong [4], Wijitpaisarn [5], Yooyong [6], Gunawan, et al. [7], Nawawi [8], and Djuhaeni [9], Thohir [10], Sahuddin [11] stated that tasks prepared by lecturers are very important in improving students' English-speaking skills.

Lee [12] defines tasks as class activities or exercises that have objectives that can be obtained only by the interaction between participants, structuring mechanisms, sequence of interactions, and a focus on the exchange of meanings. In addition, tasks refer to language learning endeavors that require learners to understand, manipulate and produce the target language as they perform a set of tasks using realworld language. According to Breen [13], the task is a structured plan that provides opportunities for students to improve their knowledge and increase their ability in the new language that is learned, and then the language is used during communication. According to Willis [14], tasks are activities in which the target language is used for communicative purposes to achieve a result. 
Tasks consist of several forms that originate from the material being taught in the form of verbal or non-verbal tasks, followed by activities that come from the subject matter. This activity requires students to be active in every activity on the material being taught. Tasks have goals and roles for teachers and students. Nunan [15] reminded that learning designers must follow the following elements when designing a task, including goals, input, procedures, teacher role, learner role, and place

The researcher believes that preparing communicative tasks in the academic speaking course will greatly assist students in developing their cognitive processes, creative thinking, and problem-solving skills. Therefore, the researcher needs to find an appropriate format for communicative tasks as an alternative to improve the English presentation skills of students at the English Language Study Program, University of Mataram. The purpose of this research is to find out the appropriate communicative assignment model to maximize the English presentation skills of students of the English Language Study Program, University of Mataram, and to identify the obstacles experienced by lecturers who teach academic speaking courses in the tasks that have been prepared.

\section{METHODS}

This research is a Research and Development, which is conducted to develop teaching materials for students in the academic speaking subject. Borg and Gall in Latief [16] state that Educational Research and Development is a research design that aims to develop and validate educational products. Furthermore, Latief [16] defines Educational Research and Development as a research design to develop educational products such as curriculum, syllabus, textbooks, learning media, modules, assessment instruments, and others.

This research was conducted to design speaking teaching materials in the academic speaking class for students of the English study program which are expected to suit the needs of students in the FKIP UNRAM academic speaking class. In this study, researchers adapted a development procedure model based on Gall [1] and adapted it based on research needs starting from: a) Obtaining information consisting of identifying problems, choosing problem-solving tools, and theoretical studies. b) Choosing teaching materials that consist of techniques, teaching, and learning processes. c) Summarize the teaching material. d) Present. d) Evaluating. e) Completion which consists of developing the final product for academic speaking teaching materials. The results of the needs assessment discuss the data collected from questionnaires, observations, and documentation.

\section{RESULT AND DISCUSSION}

The appropriate communicative tasks model to maximize students' English proficiency Presentation tasks are part of the lecturers' assessment in conveying the main ideas of their reading. There are a variety of simpler but effective ways to improve English language skills that can be taken by students. Here I present some of what was done.

\section{A. Variety Ways to Improve English Language Skills}

- Read

The first way to hone students' English language skills is to ask students to read a lot of literature in English. If students like to follow news or gossip about the world of celebrities in newspapers and magazines, then students can regularly read news from foreign sites. If students are a fan of novels or comics, ask them to read fiction and comic novels in English.

Lecturers can find various ebooks that can be read at any time from the internet, at low prices, or for free and do not cost as much money as buying English books that are printed on paper. Indeed, at first, students had difficulty understanding what they read. But with the help of a dictionary that is always with him, it helps to understand the outline he is reading.

\section{- Observe}

The meaning of observing here is of course observing all things related to English. For example; pay attention to English films that are watched, and try to live the dialogue more without glancing at the subtitles too often. Pay attention to how the actors and actresses pronounce certain phrases or use them in different contexts. A visual observation like this will provide a better perception, so students will become proficient faster. Finding out the meaning of the lyrics of your favorite songs will also help to add to your vocabulary in a fun way.

- Write

After reading and observing a lot, students' understanding of English will certainly improve. Furthermore, to further improve the students' abilities, I asked students to write their reading results in power point $(\mathrm{PPt})$ to be presented.

\section{- Presentation}

After the students made their PPt slides, I asked the students to present their reading results (offline and online).

\section{B. Constraints Experienced by Lecturers Who Teach Courses in The Tasks That Have Been Prepared}

Constraints that affect students' speaking performance are grouped into two aspects, namely linguistic and nonlinguistic. Linguistic factors include the ability to choose and use the right vocabulary according to pronouncing English words correctly and using tenses according to the context.

Meanwhile, the non-linguistic factors analyzed included aspects of self-confidence, anxiety, and mastery of the topic of the assigned material when appearing in front of class 1 . Geographies that were distributed to students after making presentations on topics showed that two aspects influenced speaking. student performance, namely the linguistic aspect consisting of vocabulary, pronunciation, and grammar. Meanwhile, non-linguistic aspects include self-confidence, anxiety, and mastery of the topic when presenting or appearing to speak in front of the class. 


\section{Questionnaire Results}

The results of the questionnaire distributed to students showed that all students got or learned new vocabulary from the tasks given by the lecturer, but still had difficulty understanding the meaning of some vocabulary that was completely new to them. Meanwhile, in terms of pronunciation, students still experience some difficulties in pronouncing English vocabulary. In grammar, students respond that they still have difficulty using and differentiating the use of English grammar.

For the non-linguistic aspect, most students still experience difficulties in terms of self-confidence. Only a few always feel confident when appearing to speak in English. Meanwhile, some students sometimes lacked confidence in presenting the slides they had prepared. The anxiety factor is also always experienced by some students. When the presentation was held, 60\% experienced anxiety when speaking English.

\section{Observation}

The observations made by the researcher during the meeting for the presentation assignment, it was found that a lot of new vocabulary was used by students, but it was found that some of the vocabularies were used that did not fit the context. Likewise, students' English pronunciation skills are generally still lacking.

From the non-linguistic aspect, it can be seen that students' self-confidence during a presentation is still low. This can be seen when the lecturer asks volunteers to start the presentation. Most of the students looked worried and hoped that their other friends would start the presentation. They were also anxious and nervous when it was their turn for the presentation, so they could not remember the contents of the material. Some chose to read the text they were carrying, some others used Indonesian or stayed silent for a long time to memorize the text they had memorized. Meanwhile, for mastery of the material, it was found that some students could explain or present well. Some of the others seem to only memorize sentences in the text but do not understand the meaning of the text.

\section{E. Documentation}

From the presentations made by students, the results of their speaking performance assessments were obtained from the lecturers. The lecturer assessment rubric shows the things that affect the speaking performance of students which are divided into two aspects, namely the linguistic and non-linguistic aspects.

In the linguistic aspect, lecturer data shows that all students use a varied vocabulary when presenting, but still have difficulty using it in the right context. Meanwhile, in terms of pronunciation, most of them still have difficulty pronouncing English vocabulary. In grammar, students also still have difficulty using it at certain times according to the context.

For the non-linguistic aspect, the lecturer notes show that most students still experience difficulties in terms of self-confidence when speaking in English. The anxiety factor experienced by most students. For mastery of the topic, some students had difficulty when they had never studied the presentation topic before.

\section{F. Factors Affecting Speaking Performance}

Two main factors that affect the speaking performance of students in speaking activities, especially in English, are linguistic and non-linguistic. Linguistic factors include vocabulary, pronunciation, and grammar. Meanwhile, nonlinguistic factors include self-confidence, anxiety, and mastery of the topic. Difficulties faced by students in speaking performance

\section{G. Linguistic Aspects}

Even though there is a lot of vocabulary that students get when preparing presentation materials with predetermined topics, it is still difficult for students to understand new vocabulary and choose the right words for certain contexts in English. The length of words in English also makes it difficult for them to memorize and pronounce the vocabulary. This is due to the tendency to use the mother tongue, namely Indonesian, where the spelling of the word and the pronunciation is the same, while in English, there is often a difference between spelling and pronunciation. Likewise with English grammar has many rules, especially the use of verbs for certain times or tenses.

However, to prepare for the presentation assignment mentioned above, some students have different ways, including reading the text repeatedly while memorizing it, looking for the meaning of vocabulary in the EnglishIndonesian dictionary, watching YouTube mimic the pronunciation of words in the language. English, and ask those who are considered to understand more English.

Meanwhile, the difficulties faced by students related to non-linguistic factors such as; self-confidence, anxiety, and mastery of topics. The student's lack of confidence when appearing in presentations is due to several things, including feeling afraid if they make mistakes using vocabulary or English when presenting. So that giving feedback or corrections from lecturers should not be done when students make presentations. This is in line with Harmer [17] who argues that speaking activities will be disturbed and not following the learning objectives when the lecturer always provides corrections on every mistake made by students.

Westrup \& Baker [18] suggest that teachers can correct students' mistakes in a positive and motivational manner. Lack of confidence creates anxiety which is sometimes excessive in the speaking performance of students, so they prefer to use Indonesian in presentations. Harmer [17] states that the reason students use their mother tongue is that it makes it easier for them to say what they want to convey because it is more natural, besides mother tongue is a natural language that is used every day so that they are more comfortable conveying their meaning. Meanwhile, mastery of the topic of the presentation is also one of the factors that affect students' speaking performance.

From their appearance, they often looked nervous and often read the notes that were taken during the presentation, indicating that they were not good at the topic being presented. James [19] argues that one of the reasons for the 
difficulty of students speaking foreign languages is that the topic chosen by the teacher/lecturer is not following the student's interest or knowledge.

\section{CONCLUSION}

The results of this study are to determine the factors both linguistic and non-linguistic that affect student performance in the academic speaking class. The linguistic factors experienced by students include vocabulary, pronunciation, and grammar. Meanwhile, non-linguistic factors include self-confidence, anxiety, and mastery of the topic.

\section{REFERENCES}

[1] Gall, Meredith Damien, Walter R. Borg, and Joyce P. Gall. Educational research: An introduction. Longman Publishing, 1996.

[2] Amrullah, Amrullah. "Improving English Speaking Ability Through Task Based Learning Approach (An Action Research At Faculty Of Teacher Training And Education University Of Mataram)." Jurnal Linguistik, Sastra dan Budaya 12.2 (2016).

[3] Prabhu, Neiman Stern. Second language pedagogy. Vol. 20. Oxford: Oxford University Press, 1987.

[4] Rattanawong, Chinnapen. "Effects of teaching by using task-based learning towards English language communicative ability of Pratom suksa six students." Unpublished MA thesis), Chulalongkorn University, Bangkok (2004)

[5] Wijitpaisarn, P. "The use of task-based learning program to enhance communicative English speaking ability of Mattayomsuksa 3 students to be young tour guides." Unpublished MA Thesis, Srinakharinwirot University (2005).

[6] Yooyong, Bancha. "The use of task-based learning to develop English speaking ability of mattayomsuksa 2 students at Banmarkkaeng school in Udon Thani province." Unpublished Master's project). Srinakharinwirot University, Bangkok, Thailand (2008).

[7] Gunawan, Iwan Dudy. Penerapan model pembelajaran berbasis tugas (Task-based learning) bagi peningkatan keterampilan berbicara bahasa inggris: Studi pada mahasiswa Perguruan Tinggi di Bandung. Diss. Universitas Pendidikan Indonesia, 2013.

[8] Nawawi. Improving English Speaking Ability through Tasks-Based Learning Approach page: 101-107 in Asian EFL JournalA Division of TESOL Asia GroupPart of SITE Ltd Australia. English Language EducationJournals 2016. http://www.elejournals.com

[9] Enny Fitriani, Nurasyah. "Kontribusi Bimbingan Kelompok Dalam Meningkatkan Etika Komunikasi Siswa." Prosiding Seminar Nasional Hasil Penelitian. Vol. 1. No. 1. 2018.

[10] Thohir, Lalu. "The Explicit Comprehension-Strategy Instruction: Question-Answer Relationship VS Self-Questioning." UNNES International Conference on ELTLT. 2017.

[11] Sahuddin. The Effectiveness of Presentation Technique in Teaching Speaking. Jurnal Gema Rinjani FKIP University of Mataram. 2017.

[12] Lee, James F. Tasks and communicating in language classrooms. McGraw-Hill, 2000.

[13] Breen, Michael P. "Contemporary paradigms in syllabus design. Part I." Language teaching 20.2 (1987): 81-92.

[14] Willis, Jane. A framework for task-based learning. Vol. 60. Harlow: Longman, 1996.

[15] Nunan, David. "Task-based language teaching in the Asia context: Defining'task'." Asian EFL journal 8.3 (2006).

[16] Latief, Mohammad Adnan. "Reliability of Language Skills Assessment Results." Jurnal Ilmu Pendidikan 8.3 (2016).

[17] Harmer, Jeremy. The practice of English language teaching. longman, 2001.

[18] Westrup, H., and J. Baker. "Essential speaking skills." New York: Continuum (2003).

[19] James, Joy. Seeking the beloved community: A feminist race reader. SUNY Press, 2013. 